\title{
THE EARLY DIAGNOSIS OF GENITAL CANCER BY CYTOLOGY
}

\author{
By ERICa Wachtel, M.D. \\ Institute of Obstetrics and Gynaecology, Hammersmith Hospital
}

The cytological diagnosis of malignant disease is based on the fact that malignant as well as normal epithelia shed their cellular constituents and that these exfoliated cells can be recovered for microscopic examination from body fluids and secretions. The method was first described by G. N. Papanicolaou in 1927 at The Third Race Betterment Congress, but did not arouse any general interest until r943, when Papanicolaou and Traut published their standard textbook on Uterine Cancer Diagnosis by Vaginal Smear, after perfecting their staining technique. Since then, the method has been extended to cancer detection in other organs, foremost to the diagnosis of lung carcinoma from the sputum.

The diagnosis of uterine malignancies is made by examination of vaginal and cervical secretions or by direct scraping of the squamo-columnar junction with a wooden spatula. The latter method was described by Ayre and is known as the 'surface biopsy.' It has the obvious advantage of avoiding dilution of the material and provides an excellent means of examining directly any 'suspicious-looking' area of the cervix uteri. On the other hand, this very precision of the method carries the disadvantage that it is directed only against the cervix and does not allow for collection of material from other sites of the genital tract.

Papanicolaou's original technique of aspirating material from the posterior fornix collects cells from the entire genital tract and thus enables the cytological detection of unsuspected malignancies in the cervix as well as in the uterine body and occasionally also in the ovaries. This method, (though more troublesome for the cytologist owing to the great deal of dilution due to the wide area from which material is collected), is more reliable in our opinion for cancer detection in symptomless patients, and recommends itself strongly for routine use. Surface biopsy should be reserved as an additional method of investigation and should certainly be employed in any patient presenting cervical pathology.
Aspiration is carried out with a piece of slightly $\frac{\omega}{\sigma}$ curved glass tubing to which a rubber bulb is $\frac{0}{7}$ attached at one end (Fig. I). The free end of the 3 . tube is introduced into the posterior fornix while ${ }^{\omega}$ the bulb is compressed; when in position, the $\omega$ pressure on the bulb is gradually reduced while of the tube is slowly. moved sideways so that the $\mathcal{O}^{\omega}$ fluid from the entire area is collected. This

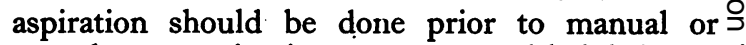
speculum examination as contact with lubricants must be avoided.

The introduction of the glass tube and the subsequent aspiration are completely painless $8 \overrightarrow{0}$ the patient and it is such an easy procedure thet: patients can be taught to take their own smears; which is a great help wherever serial smears a required. (As in hormonal assessments.)

Surface biopsies necessitate the use of a speculum. The cervix is exposed and a wooden $\stackrel{\square}{\square}$ spatula similar to those used for throat examinations, but trimmed into a suitable shape (Fig. 2)을 is drawn round the squamo-columnar junction, $\frac{}{\partial}$ using slight pressure so that the surface epithelium is scraped off.

Whatever method of collection of material is 3 used, the subsequent procedure is identical. Thin, even smears are made on glass slides which are immediately, when still wet, immersed in the $\delta$ fixing fluid where they remain for a minimum period of 15 minutes but may be left for as long as 응 7-8 days. In suitable portable fixing jars with a screw-cap top, they can be posted to a cytologicalo laboratory. Immediate wet fixation of the slides is an important detail as air-dried smears do not? absorb the stains. Fixing fluids in use are ether- $N$

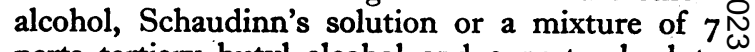
parts tertiary butyl alcohol and 3 parts absolute alcohol, which is the most stable of the three.

The staining of the slides is carried out in the

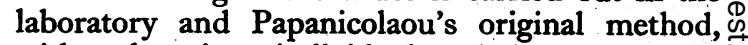
with only minor individual variations according $\tau$ to the predilection of the cytologist, is still in use. For details of the technique the reader is referred $\mathbb{\mathbb { D }}$ to Papanicolaou and Traut's book (1943). The $\frac{\mathcal{O}}{\Phi}$ 


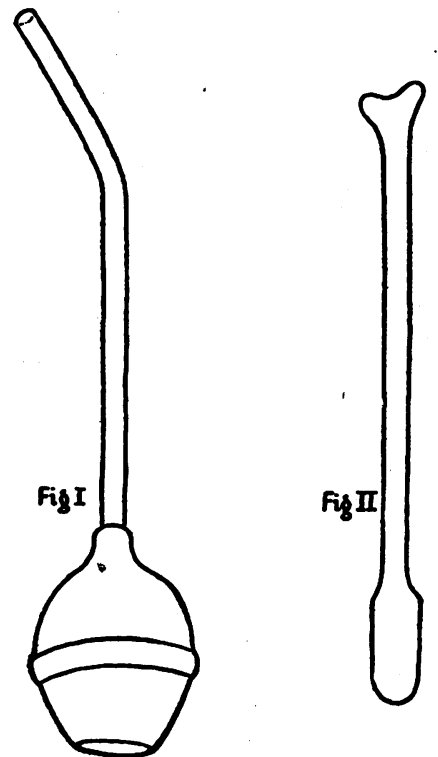

FIG. I.-Apparatus for posterior fornix aspiration. Fig. 2.-Wooden spatula for 'surface biopsy.'

stained and mounted slides are ready for microscopy.

Before discussing the criteria of malignant cells it is necessary to say a few words about the normal cells present in all smears and to describe certain abnormalities other than malignant features. It is essential to become thoroughly familiar with the normal vaginal cytology and its variations in inflammatory conditions before proceeding to the detection of malignant cells.

The vast majority of cells found in normal vaginal smears come from the squamous epithelium. Scrapings from the cervix also contain normally a large number of columnar cells from the endocervix. Endocervical cells in aspiration smears are unusual and generally indicate cervical pathology such as cervicitis, cervical polypi or erosion. Endometrial cells in posterior fornix aspirations are seen physiologically during or shortly after the menstrual period, but are pathological at any other phase of the cycle, indicating an abnormal endometrium.

Squamous cells occur in 3 varieties according to the layer from which they have exfoliated. A healthy vaginal epithelium in a young woman shows a superficial, an intermediate and a basal layer. Normally in young women only cells from the 2 upper layers are recovered in the aspiration. In cases of severe infection, however, where the surface layer has become eroded by the inflammatory process, basal cells from the lowest layer will also be seen and their percentage indicates the severity of the inflammatory destruction. Conversely, thinning of the epithelium with loss of surface layers, occurs with failing ovarian function and can be recognized by the presence of basal cells in the smear in the absence of infection.

Superficial squames are the largest cells found in vaginal or cervical smears. They are polyhedral cells with a clear cytoplasm staining bluegreen or red with the acidophilic or basophilic stains of the triple dye. Some authors regard the staining reaction as a function of oestrogen activity, describing acidophilic cells as oestrogenized, but we consider the staining reaction to be dependant on the $\mathrm{pH}$ of the vagina and make no attempt to correlate it to the oestrogen level. The nuclei of these superficial (and intermediate) squames are, however, of primary importance in hormone estimations. They have either a vesicular nucleus which is small and, under normal conditions, does not exceed $1 / 5^{\circ}$ of the cell volume, or a punctate, pyknotic nucleus. We believe that nuclear pyknosis is an oestrogen effect and work out the percentage of pyknotic nuclei (Cornification Index $=\mathrm{CI}$ ) to establish the oestrogen level. The CI in a given patient is not a stable figure but varies with the stage of the cycle reaching a peak value at ovulation. Cornification indices after the menopause are normally extremely low.

Progesterone effects on these cells are also recognizable, i.e., the cells which in the proliferative and ovulatory phase appear clear cut with smooth, sharply defined edges, cluster together and show edge curling (envelope effect) under progesterone influence.

Intermediate squames are smaller and rounder than superficial cells and have a somewhat larger nucleus. They are specifically increased in pregnancy when they may be boatshaped (navicular cells of pregnancy).

Basal cells are the smallest cells of the squamous epithelium. They are round or oval, have a large round nucleus which does not exceed normally $\frac{t}{b}$ of the cell volume, and usually stain blue-green. They very often show degenerative changes, i.e., vacuolization of the cytoplasm, perinuclear halo formation and karrhyorrhexis. Since they indicate failing ovarian function, they are prevalent in postmenopausal women. Their percentage in any given smear, provided there is no infection present, gives a fair measure of the regressive changes occurring in the patient (Fig. 3).

The columnar epithelium seen in smears differs very strikingly in size from the squamous cells. Endocervical cells are pear-shaped cells, about 3 times as big as a lymphocyte with a rounded lower pole and a flattened upper end bearing cilia. The nucleus stains dark, fills about $\frac{1}{3}$ of the cell and 
lies eccentrically in the lower pole. The cytoplasm is pale, clear and stains blue-green. These cells have an unfortunate habit of rapid disintegration so that often only clusters of dark staining nuclei with little or no cytoplasm are found. These could be misinterpreted as malignant nuclei if one were not familiar with their appearance, especially since they often show inflammatory changes. Characteristic for their innocent nature is the smooth nuclear outline, the uniformity of nuclear size and shape, and the even or finely granular nuclear structure (Fig. 4).

Endometrical cells are the smallest epithelial constituents found in smears. They are not bigger than one and a half to twice the size of a lymphocyte, which they resemble to a certain extent. They are round cells with a relatively large nucleus filling $\frac{1}{4}$ to $\frac{1}{3}$ of the cell volume and a clear cytoplasm, rather more dense than that of endocervical cells, which usually stains blue-green. They possess the same tendency to rapid disintegration as endocervical cells and appear also very frequently as clusters of nuclei only. Again, this may present diagnostic difficulties.

When looking at a series of smears through the microscope one finds two groups of films: the "clean" and the "dirty" patterns. The former are composed of normal epithelial cells only or may show Doederlein bacilli or a few leucocytes as well. They are characterized by an essentially uniform pattern throughout the entire film, can be screened quickly and present no difficulties in diagnosis. They rarely, if ever, contain malignant cells.

The second group, " the dirty film," is composed of clusters of cells and there is an excess of leucocytes and bacteria and often also of red blood corpuscles. There is no uniformity of appearance. in any two microscopic fields and screening these films is a long and wearisome task. Such patterns may indicate a great variety of conditions. They are physiological during menstruation, or pathological in inflammatory or malignant disease.

Inflammatory nuclear changes present an extremely complex appearance including variations in size, shape, staining properties, hyperchromasia and granular structure. However abnormal the nuclei may appear the differentiating characteristics from malignancy are:

I. Although the nuclei may be enlarged, they are smaller than $\frac{1}{3}$ of the cell volume.

2. Their granules are fine and even and do not show variations inside the same nucleus. Malignant films are almost always "dirty" films. They show clumping of the " normal" epithelium, a great many abnormal cells with inflammatory nuclear changes exfoliated from sites adjacent to the neoplastic area, malignant cells from the tumour, leucocytes and bacteria in excess and usually, though not necessarily soz many red blood corpuscles. The cornification $\mathbb{b}$ index of a " malignant smear" is usually high $\leftarrow$ which is especially striking in cancer patients welle: past the menopause.

The number of malignant cells found in $\bar{x}$ smear depends on the exfoliative properties of the tumour and the degree of dilution occurring. As a rule, the younger the carcinoma, the more readily does it exfoliate and the easier the recoveryen of these cells in the smear. Well established carcinomata of long standing often fail to shed recognizable cancer cells into the vaginal secretions $\vec{\omega}$ probably because these tumours have ulcerateof surfaces with superimposed infection. Howevero these cancers are clinically obvious and cytologicap. diagnosis would, in any case, be of academic interest only. It is far more important from jy practical point of view, that the early neoplasmer usually exfoliates readily and that its cells can ben discovered by routine screening at a time before clinical signs and symptoms are apparent.

Cancer cells, irrespective of their origin, are identified by their nuclei. The pathognomonic features of malignancy are the coarse granular structure of the nucleus and the variation in. siaes and shape of the individual granules inside same nucleus. Other features suggestive, but diagnostic, of malignancy are nuclear enlargement irregularity of nuclear outline and hyperchromasia

Well differentiated malignant cells resemble the epithelium of their origin and thus indicate not only the presence of malignant disease but als $\vec{b}$ the source and type of the tumour. No difficulty arises in differentiating cytologically between squamous- and columnar-celled cancers, if the new growth is composed of at least moderately well differentiated carcinoma cells. Very im? mature and anaplastic tumours may, however? present great diagnostic problems as to the tissue from which they are derived, although the recognio tion of their malignant character is easy. Similar difficulties are encountered in histological sections of such cases.

Differentiated squamous cancer cells occur in:3 varieties according to the epithelial layer frongs which they originate:

I. Malignant tadpole cells (corresponding tकి superficial squames). Fig. 5 .

They are the largest malignant cells found if smears. Their appearance resembles a tadpole Note the large nucleus filling more than thof th cell, its granular structure and the variation in size and shape of the individual granules.

2. Malignant fibre cells, derived from thळ intermediate layer, are thin fibre like cells witl? 


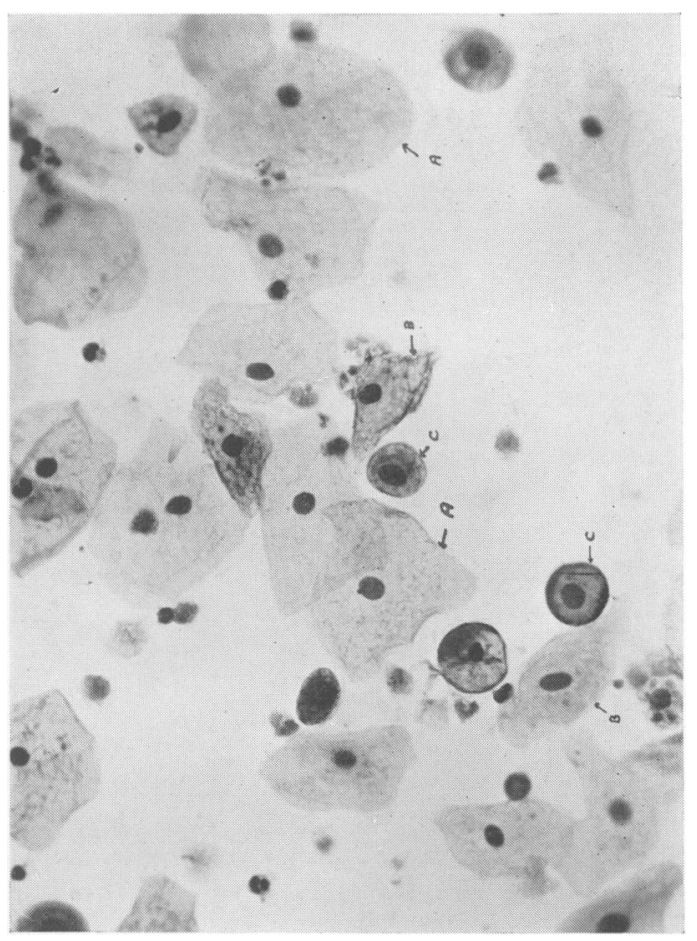

Fig. 3.-Normal vaginal epithelium of a menopausal woman. (a) Superficial squame. (b) Intermediate squame. (c) Basal cell. $\times 400$.

a large elongated nucleus filling at least $\frac{1}{3}$ of the cell volume.

3. Malignant basal cells (Fig. 6) derived from the deepest epithelial layer, usually exfoliate in clusters. These are the most commonly found squamous malignant cells in smears.

Malignant endocervical and endometrial cells closely resemble their benign cells of origin but have " malignant" nuclei.

Fig. 7. Malignant endocervical cells.

Fig. 8. Malignant endometrial cells.

It is frequently stated in the literature that it is much more difficult to recognize malignant columnar cells than squamous cancer cells. This is a fallacy. Apart from the difference in celland consequeritly also in nuclear size, the criteria of malignancy are identical. In addition, endometrial as well as endocervical carcinomata tend to exfoliate in clusters and notwithstanding their rapid cytoplasmic degeneration the accumulation of malignant nuclei in heaps renders the diagnosis easy. It is, of course, of paramount importance to bear in mind the size-relationship and to screen the smaller cellular elements of the film with great care.

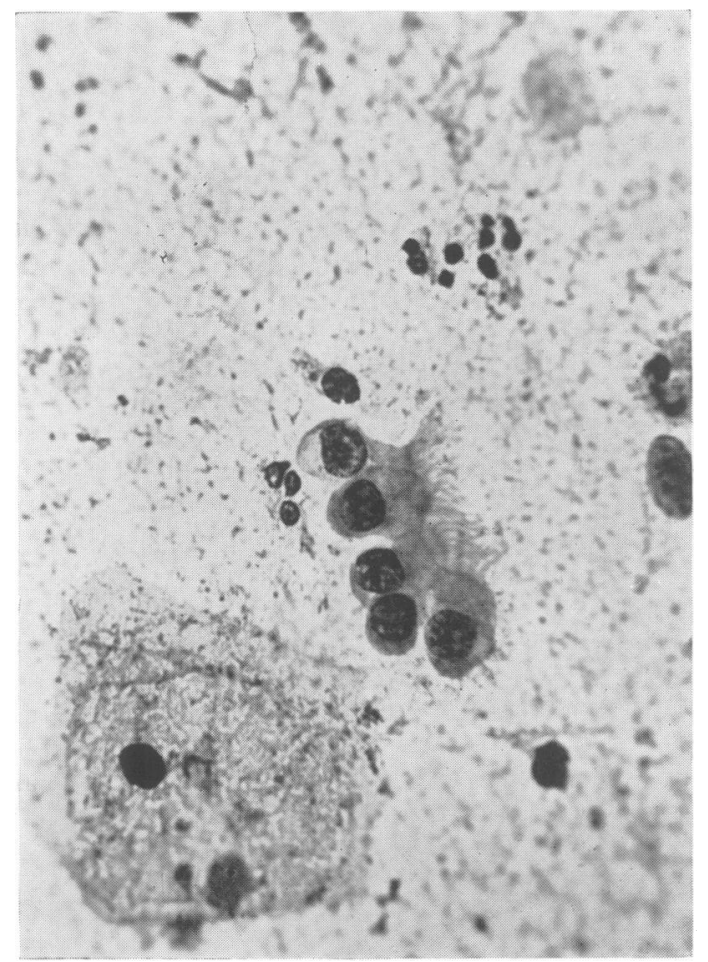

FIG. 4.-Normal perfectly preserved endocervical cells. (Note cilia at upper pole). $\times_{1,000}$

The role of vaginal smears in cancer diagnosis is still much debated. We hold that cytology plays a definite part in gynaecology when used by specialists with a critical mind, well aware of its limitations. It is the most valuable means we have at the present moment of recognizing malignant disease in its initial stages. It is not customary to submit the patient who seeks gynaecological advice for symptoms which do not suggest malignant disease of the genital tract and in whom no clinical signs are as yet apparent to curettage or biopsy. Cytological investigations can, however, easily be included into the routine tests and if cancer cells are present in the smear, this finding justifies further histological examination and enables the gynaecologist to provide treatment at a very early stage of the disease.

Cytological cancer diagnosis is by no means an infallible procedure. Mistakes do occur owing to failure of exfoliation or to error of judgement, but despite these shortcomings the sum total of correct diagnoses does not compare badly with the results of other laboratory methods. It must be borne in mind that biopsy is also not an infallible diagnostic test, since in the patient without clinical evidence of malignant disease, the removed tissue may have 


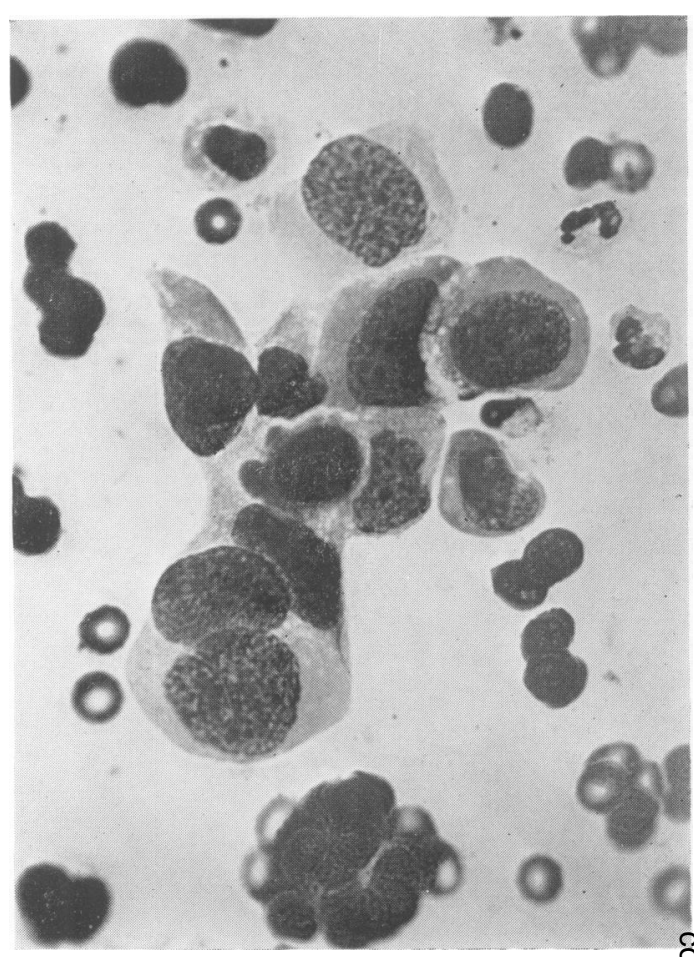

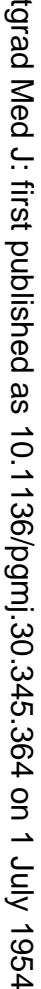

Fig. 5.-Tadpole cell. (Note enlarged hyperchromatic nucleus with coarse irregular granulation). $\times$ I,000.

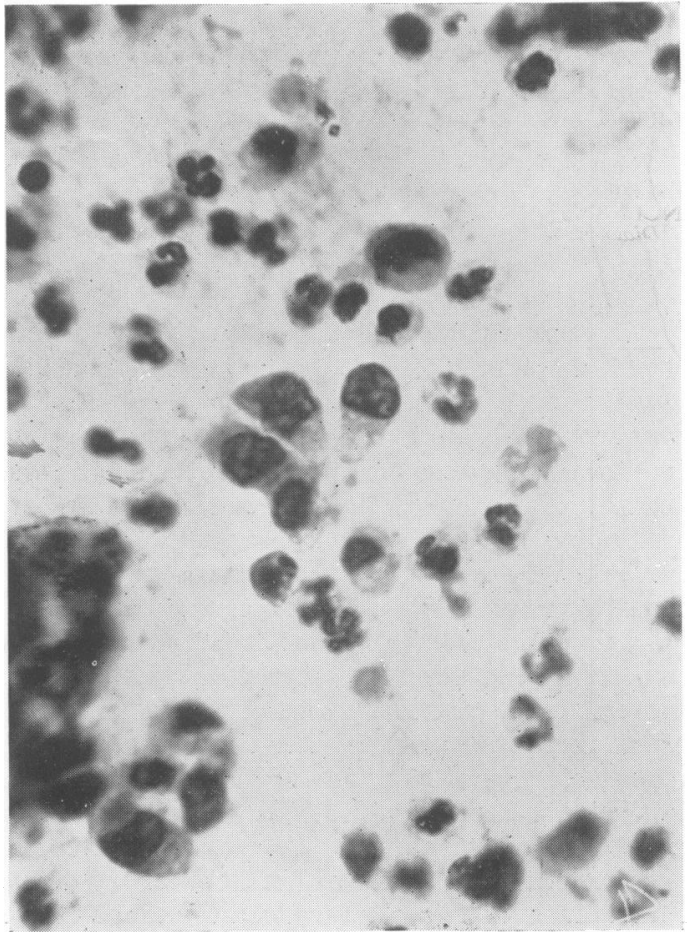

FIG. 7.-Malignant endocervical cells. $\times_{1,000}$

FIG. 6.-Malignant basal cells. (Showing enlarge hyperchromatic, coarsely granular nuclei wi irregular outlines. $\times \mathrm{I}, 000$.

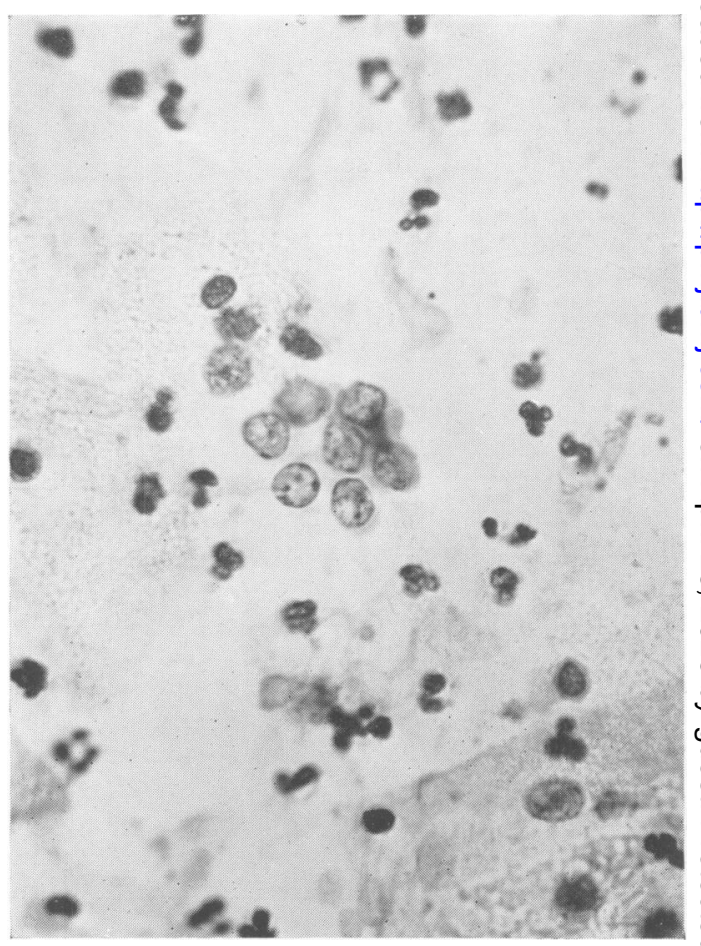

Fig. 8.-Malignant endometrial cells. $\times$ I,000. श 
been taken from an area free of new growth. If both methods are employed the overall cancer detection will be increased. Errors in judgment are mainly responsible for ' false positive' reports, and it is, therefore, imperative to confirm 'positive smears' by histological methods before any therapeutical measures are taken. 'Positive smears' which are unsupported by histology should be repeated; if follow up smears continue to show cells believed to be malignant, more extensive repeat biopsies must be carried out, but on no account should a patient be submitted to major surgery or radiotherapy on the strength of one positive smear report.

A survey of the 3 years' ending December 31, 1952, routine cytological screening carried out at the Hammersmith Hospital gave the following results: The total number of patients suffering from malignant disease of the uterus seen in the Gynaecological Department was 64; 30 of these were squamous and 34 columnar-celled malignancies.

Of the 30 squamous cancers 26 were diagnosed correctly by routine smear procedure, 3 or ro per cent., were missed and for one an unsuitable smear had been submitted. This compares well with American figures of ' false negatives.'

Of the 34 adenocarcinomata 3 I were diagnosed correctly, two were missed and for one an unsuitable film had been submitted. This gives an incidence of error of only 5.8 per cent., which is much lower than the corresponding American figures.

More important than these absolute figures is the fact that out of these 64 carcinomata 8 were entirely unsuspected clinically and would not have been diagnosed and treated at this early stage had cytological investigation not been carried out.

The incidence of false positive reports has been regrettably high, but as the only criterion of comparison is the histological report, which is regarded as the ultima ratio although it is sometimes based on a single biopsy only, it is possible that cases now listed as cytological errors, may, in the course of time, prove to have been correctly diagnosed cytologically. One case included in the 64 carcinomata had been listed as a 'false positive' for 18 months until the patient was re-admitted with secondary vault metastases. (Martin and Kenny $195^{\circ}$ and Martin 1953).

In the light of our present knowledge, however, and accepting the histological report as the final judgement, we have had 9 ' false positive' reports, all of which concerned erroneous diagnoses of columnar-celled malignancies; most of these came from patients with ulcerating polypi, one from a patient with a sloughing endometrium and one from a woman diagnosed as an atypical glandular hyperplasia.

To sum up: of our 62 carcinomata investigated cytologically, omitting the two cases with unsuitable smears, 57 or 91.9 per cent. were diagnosed correctly, 5 or 8.7 per cent. were ' false negatives,' and 8 were detected by the smear. Cytology is a valuable aid to cancer diagnosis and an easily applicable method of cancer detection in the unsuspected case.

\section{BIBLIOGRAPHY}

AYRE, J. ERNEST, (1951), Cancer Cytology of the Uterus, New York, Grune and Stratton.

MARTIN, R. T. and KENNY, M. (1050), ' Changes in the Cervix Uteri simulating Carcinoma in Two Successive Pregnancies,' F. Obstet and Gynaec, Brit. Emp., 7, 608 .

MARTIN, R. T., F. Obstet. and Gynaec., Brit. Emp., (in press).

PAPANICOLAOU, G. N. and TRAUT, H. F. (1943), Diagnosis of Uterine Cancer by the Vaginal Smear, New York, The Commonwealth Fund.

VINCENT MEMORIAL HOSPITAL (1950), The Cytological Diagnosis of Cancer, Philadelphia, W. B. Saunders Co.

WACHTEL, E. and PLESTER, J. A. (1952), 'The Vaginal Smear as an Aid to Diagnosis of Genital Tract Malignancies in Women.' F. Obstet. and Gynaec., Brit. Emp., 3, 323.
Continuation of Bibliography-H. P. Ferreira, M.D., from page 359.

BELLERBY, C. W. (1934a), Nature, 133, 494.

BHADURI, J. L. (1951), Proc. 38th Ind. Sci. Congress, Pt. II, 171. BINET, L., VERNE, J., and LUXEMBOURG, F., C.R. Soc. Biol., Paris, 116, 1241 .

BISHOP, P. M. F. (1934), Brit. med. Y., i, 1186.

BROUHA, L., and HINGLAIS, H. (1931), Gynec. et Obstet., 24, 42. BRUHL, R., and REIKOFF, W. (1935), Z. Geburtsh. Gynak., II2, $\mathrm{T}$.

BUNDE, C. A. (1947), Amer. F. Obstet. Gynec., 53, 317

COWIE, A. T. (1948), 'Pregnancy Diagnosis Tests: A Review.'

ELEK, S. D. (1953), Personal Communication.

FARRIS, E. J. (1944), Amer. Y. Obstet. Gynec., 48, 200

FRAZER, J. F. O., and WOHLZOGEN, F. X. (1950), Brit. med. F., il, 330 .

FRIEDMAN, M. H. (1929a), Proc. Soc. exp. Biol., N.Y., 26, 720. GALLI MAININI, C. (1947a), Sem. med., 54 (I), 337.

GALLI MAININI, C. (1948), $\%$. Amer. med. Ass., 138, 121.

GEOGHEGAN, F., and MCGRATH, J. (1944), Irish' Y. med. Sci., 6 'm Ser., No. 225,509 .

HAINES, M. (1948), Lancet, ii, $255,923$.

HAINES, M., and FERREIRA, H. P. (1954), in the Press.

HOBSON, B.' M. (1952), F. Obstet. and Gyn. Brit. Emp., 59, 3, 352.

HOGBEN, L. (1930), Proc. Roy. Soc. Afr., 5 , 19 HOUSSAY, B. A., and LASCANO GÖNZALEZ, J. M. (1929),
Rev. Soc. argent. Biol., 5. 77.

HUMMEL, K. P. (1942), Endocrinology, 30, 74
KONSULOFF, S. (1934), Klin. Wschr., 13, 776.

KRAUS, E. J. (1932), Munch. med. Wschr., 79, 214

KUPPERMAN, H. S., and GREENBLÄTT, R. B. (1946), Sth. med. Э. (B'gham, Ala.), 39, 158.

KUPPERMAN, H.' S., GREENBLATT, R. B., and NOBACK, C. R. (1943), 今. clin. Endocr., 3, 548.

LANCET (1948), ii, 977 .

LANDGREBE, F. W. (1939), F. exper. Biol., r6, 80.

LANDGREBE, F. W. (1948), Proc. Roy. Soc., Edinburgh, 63, 213. LAW, J. W. (1949), Bull. Inst. Med. Lab. Tech., 14, 1 1, 175.

OWEN, S. E. (1936), Endocrinology, 20, 214.

POU DE SANTIAGO, A. (1947b), Arch. Moguayos Med. Arng.

Espec., 30, 457. REIPRICH, W. (1933), Klin. W schr., 12, 1441.

REIPRICH, W. (1934), Z. Geburtsh.' Gynak., 109, 285.

SALMON, N. J., GEIST, S. H., SALMON, A. A., and FRANK, I. L. (1942), $\%$ clin. Endocr., $2,167$.

SCHWABACHER (1951), Med.' Press, 226, 82.

SCOTT, L. D. (1940), Brit. F. exp. Path., 21, 320.

SHAPIRO, H. A., and ZWARENSTEIN, H. (1934a), Nature, SI33, 339.

SIMOLA, P. E., and RIVAS, L. (1936), Suom Kemist., 9, B, 24.

WALKER, T. F., and WALKER, D. V. H. (1938), Э. Amer. med.

Ass., III, 1460. 